\title{
Human umbilical cord mesenchymal stem cells increase interleukin-9 production of $\mathrm{CD4}^{+} \mathrm{T}$ cells
}

\author{
ZHOU XIN YANG ${ }^{1,2^{*}}$, YING CHI ${ }^{*}$, YUE RU JI ${ }^{1}$, YOU WEI WANG ${ }^{1,3}$, JING ZHANG $^{2}$, \\ WEI FENG LUO ${ }^{4}$, LI NA $\mathrm{LI}^{4}$, CAI DONG HU⿱4${ }^{4}$, GUANG SHENG ZHUO, \\ LI FANG WANG ${ }^{6}$, ZHI-BO HAN ${ }^{1,3}$ and ZHONG CHAO HAN ${ }^{1,3}$
}

\author{
${ }^{1}$ The State Key Laboratory of Experimental Hematology, Institute of Hematology and \\ Hospital of Blood Diseases, Chinese Academy of Medical Sciences and Peking Union of Medical College, \\ Tianjin 300020; ${ }^{2}$ Zhejiang Provincial Key Laboratory of Geriatrics, Zhejiang Hospital, Hangzhou, Zhejiang 310013; \\ ${ }^{3}$ National Engineering Research Center of Cell Products, Tianjin 300457; ${ }^{4}$ School of Medicine, Jinan University, \\ Guangzhou, Guangdong 510632; ${ }^{5}$ Beijing Institute of Health and Stem Cells, Beijing 100176; ${ }^{6}$ Department \\ of Basic Medicine, Zhejiang Medical College, Hangzhou, Zhejiang 310053, P.R. China
}

Received August 16, 2016; Accepted July 12, 2017

DOI: $10.3892 / \mathrm{etm} .2017 .4952$

\begin{abstract}
Mesenchymal stem cells (MSC) are able to differentiate into cells of multiple lineage, and additionally act to modulate the immune response. Interleukin (IL)-9 is primarily produced by cluster of differentiation (CD) $4^{+} \mathrm{T}$ cells to regulate the immune response. The present study aimed to investigate the effect of human umbilical cord derived-MSC (UC-MSC) on IL-9 production of human $\mathrm{CD} 4^{+} \mathrm{T}$ cells. It was demonstrated that the addition of UC-MSC to the culture of $\mathrm{CD} 4^{+} \mathrm{T}$ cells significantly enhanced IL-9 production by $\mathrm{CD} 4^{+} \mathrm{T}$ cells. Transwell experiments suggested that UC-MSC promotion of IL-9 production by $\mathrm{CD} 4^{+} \mathrm{T}$ cells was dependent on cell-cell contact. Upregulated expression of CD106 was observed in UC-MSC co-cultured with $\mathrm{CD}^{+} \mathrm{T}$ cells, and the addition of a blocking antibody of CD106 significantly impaired the ability of UC-MSC to promote IL-9 production by $\mathrm{CD}^{+} \mathrm{T}$ cells. Therefore, the results of the present study demonstrated that UC-MSC promoted the generation of IL-9 producing cells, which may be mediated, in part by CD106. The findings may act to expand understanding and knowledge of the immune modulatory role of UC-MSC.
\end{abstract}

Correspondence to: Dr Zhi-Bo Han or Dr Zhong Chao Han, The State Key Laboratory of Experimental Hematology, Institute of Hematology and Hospital of Blood Diseases, Chinese Academy of Medical Sciences and Peking Union of Medical College, 288 Nanjing Road, Tianjin 300020, P.R. China

E-mail: zhibohan@163.com

E-mail: hanzhongchao@hotmail.com

*Contributed equally

Key words: mesenchymal stem cells, CD4 ${ }^{+} \mathrm{T}$ cells, IL-9, CD54, CD106

\section{Introduction}

Mesenchymal stem cells (MSC) can differentiate into cells of mesenchymal tissues, including bone, cartilage, fat, tendon, muscle, and can also differentiate to cells with visceral mesoderm, neuroectoderm and endoderm characteristics in vitro (1). Therefore, MSC is considered to be a promising material for tissue engineering and regenerative medicine. MSC were first isolated from bone marrow (BM) (2), and now it can be isolated from other tissues, such as adipose (3), umbilical cord (4) and placenta (5). MSC can modulate the immune response, and there were many researches focusing on the effect of MSC on cluster of differentiation (CD) $4^{+} \mathrm{T}$ cells. BM-MSC can induce a Th1 to Th2 shift, increase Treg population (6) and inhibit Th17 differentiation (7). Both cell-cell contact and soluble factors were important for immune modulation of MSC. Prostaglandin E2 (PGE2) and indoleamine 2,3-dioxygenase 1 (IDO1) were most studied soluble factors that regulated the $\mathrm{CD} 4^{+} \mathrm{T}$ cells. PGE2 can inhibit interferon- $\gamma$ (IFN- $\gamma$ ) production and Th1 polarization of $\mathrm{CD} 4^{+} \mathrm{T}$ cells (8). IDO1 can consume tryptophan, and the lack of tryptophan leads to proliferation inhibition of $\mathrm{CD} 4^{+} \mathrm{T}$ cells $(9,10)$. Cell surface molecules, like CD106, were also supposed to be important for regulation of $\mathrm{CD} 4^{+} \mathrm{T}$ cells, probably through enhancing the crosstalk of MSC and $\mathrm{CD}^{+}{ }^{+} \mathrm{T}$ cells (11).

Human umbilical cord derived-MSC (UC-MSC) are considered to be a promising candidate for BM-MSC in many therapeutic applications. UC-MSC share many common characteristics with BM-MSC but there are some exceptions. UC-MSC could adhere to plastic and proliferate more quickly than BM-MSC (4). Although most of the surface markers were similar, UC-MSC had higher expression of CD54, SSEA-4, and OCT-4 than BM-MSC (8). Like BM-MSC, UC-MSC could modulate the immune response, inhibit IFN- $\gamma$ secretion of $\mathrm{CD}^{+}$and $\mathrm{CD} 8^{+} \mathrm{T}$ cells through a PGE2-dependent mechanism (8). These similarities suggest a common effect of MSC, and UC-MSC might be used in immune diseases 
that BM-MSC are supposed to be effective. Indeed, UC-MSC have been proved to be effective for treatments of acute lung injury (12), inflammatory bowel disease (13) and systemic lupus erythematosus (14) in animal models. As UC-MSC can be isolate more easily, UC-MSC are thought to be a useful tool for cell based therapy.

Interleukin (IL)-9 can be secreted by $\mathrm{CD}^{+} \mathrm{T}$ cells and mast cells. It regulates many hematopoietic cells, stimulates cell proliferation and prevents apoptosis (15). IL-9 had been supposed to be secreted by Th2 cells, but it is suggested that IL-9-producing CD $4^{+} \mathrm{T}$ cells is a novel $\mathrm{CD} 4^{+} \mathrm{T}$ cell subset, named Th9 $(16,17)$. Th9 is one type of effector T cells, which can promote tissue inflammation (17). IL-9 induce differentiation of Th17 cells, and enhance the function of FoxP3 ${ }^{+}$natural regulatory T cells (18), suggesting an important role in immune response. TGF- $\beta$ and IL-4 are critical for generating Th9 (17), and cytokines like type I IFNs, IL-21 and IL-1 regulate IL-9 production $(19,20)$, indicating a complex cytokine network in the regulation of human IL-9-producing $\mathrm{CD}^{+} \mathrm{T}$ cells.

MSC might be candidate cells supporting Th9, and the effect of MSC on Th9 has not been studied yet. In the present study, we discovered that UC-MSC promoted IL-9 production of cord blood $\mathrm{CD}^{+}{ }^{+} \mathrm{T}$ cells, and the effect of UC-MSC was largely depended on cell-cell contact. These results discovered that this novel type of Th can be regulated by MSC, expanding the knowledge for Th9 differentiation.

\section{Materials and methods}

Generation of human UC-MSC. This study was approved by the Institutional Review Board of Chinese Academy of Medical Sciences and Peking Union Medical College (Tianjin, China). Umbilical cords and cord blood were obtained from donors with written informed consent. The isolation and expansion of UC-MSC were performed as described previously (4). Briefly, the cord was cut into small pieces $\left(1-2 \mathrm{~cm}^{2}\right)$, and digested with $0.075 \%$ collagenase II (Sigma, St. Louis, MO, USA) for $30 \mathrm{~min}$ and then $0.125 \%$ trypsin (Gibco, Grand Island, NY, USA) for $30 \mathrm{~min}$ with gentle agitating at $37^{\circ} \mathrm{C}$. The digested mixture was passed through a $100-\mu \mathrm{m}$ filter to collect cell suspensions. Cells were washed with phosphate-buffered saline for three times and placed in plastic flasks in the presence of the complete DF-12 medium (Gibco) containing 10\% fetal bovine serum (FBS) (HyClone, Logan, UT, USA), 2 mM glutamine, $100 \mathrm{U} / \mathrm{ml}$ penicillin-streptomycin, and $10 \mathrm{ng} / \mathrm{ml}$ epidermal growth factor (EGF; Peprotech, Inc., Rocky Hill, NJ, USA). NonadherenT cells were removed from culture $72 \mathrm{~h}$ later. Once $60-80 \%$ confluence reached, adheren T cells were replanted to for expansion. UC-MSC of passage 4 to 6 were used in this study.

Flow cytometry analysis. Phenotype of UC-MSC was analyzed using the following antibodies: FITC-conjugated-CD31, CD34, CD45 and HLA-ABC; PE-conjugated- CD11b, CD19, CD29, CD44, CD54, CD80, CD86, CD73, CD90, CD105, CD106, CD117, CD151 and HLA-DR. Non-specific isotype-matched antibodies served as controls.

Osteogenic and adipogenic differentiation. Osteogenic and adipogenic differentiation were carried out as described previously (4). Briefly, $2 \times 10^{3}$ cells were plated in to a well of 96-well plates. The medium was changed with specific induction medium $24 \mathrm{~h}$ later. For osteogenic induction, STEMPRO Osteogenesis Differentiation kit (Gibco) was used. For adipogenic induction, medium consisted of DMEM supplemented with $10 \% \mathrm{FBS}, 1 \mu \mathrm{mol} / 1$ dexamethasone, $5 \mu \mathrm{g} / \mathrm{ml}$ insulin, $0.5 \mathrm{mmol} / \mathrm{l}$ isobutylmethylxanthine (IBMX), and $60 \mu \mathrm{mol} / \mathrm{l}$ indomethacin were used. Reagents for adipogenic induction were purchased from Sigma. After 3 weeks of induction, the cells were stained using alizarin red $\mathrm{S}$ or Oil Red solution $\mathrm{O}$.

Isolation of cord blood $C D 4^{+} T$ cells. Human cord blood mononuclear cells were isolated by Ficoll-Paque (Axis-Shield, Oslo, Norway) density gradient centrifugation from blood of health volunteer donors. $\mathrm{CD}^{+} \mathrm{T}$ cells were purified by using relevant magnetic MicroBead kits (Miltenyi Biotec $\mathrm{GmbH}$, Bergisch Gladbach, German) according to the manufacturer's instructions. The purity of $\mathrm{CD}^{+} \mathrm{T}$ cells was more than $95 \%$.

$C D 4^{+} T$ cells and MSC co-culture experiments. MSC were plated and allowed to adhere in 96-well or 24-well flat-bottom plate for $4 \mathrm{~h}$ at $37^{\circ} \mathrm{C}$, and then $\mathrm{CD}^{+} \mathrm{T}$ cells $\left(4 \times 10^{4}\right.$ for 96 -well plate, $2 \times 10^{5}$ for 24 -well plate) were added. These cells were cultured in complete RPMI-1640 medium (Gibco) containing 10\% FBS, $2 \mathrm{mM}$ glutamine, $100 \mathrm{U} / \mathrm{ml}$ penicillin and streptomycin, $0.1 \mathrm{mM}$ nonessential amino acids, $1 \mathrm{mM}$ sodium pyruvate. IL4 (Peprotech; $20 \mathrm{ng} / \mathrm{ml}$ ), IL-2 (Peprotech; $10 \mathrm{ng} / \mathrm{ml}$ ) and Dynabeads Human T-Activator CD3/CD28 (Life Technologies, Grand Island, NY, USA) were added to induce IL-9 production of $\mathrm{CD}^{+}{ }^{+} \mathrm{T}$ cells. $\mathrm{CD} 4^{+} \mathrm{T}$ cells and MSC were cultured for $96 \mathrm{~h}$. For blocking experiments, $5 \mu \mathrm{g} / \mathrm{ml}$ isotype control and CD106 neutralizing antibody (Ancell, Bayport, MN, USA) was added to the culture medium. For intracellular staining, CD4 ${ }^{+} \mathrm{T}$ cells were stimulated for $5 \mathrm{~h}$ with PMA (50 ng/ml; Sigma) and ionomycin ( $1 \mu \mathrm{g} / \mathrm{ml}$; Calbiochem; EMD Millipore, Billerica, MA, USA) in the presence of Golgiplug (BD Biosciences, Franklin Lakes, NJ, USA) after $91 \mathrm{~h}$ of culture. After labeled with FITC anti-CD4 mAb, cells were fixed, permeabilized and stained with PE- anti IL-9 mAb. Cells were analyzed by flow cytometry in a FACS Calibur, using the CellQuest software (BD Biosciences).

ELISA. Cell-free supernatants were collected and kept in refrigerator at $-80^{\circ} \mathrm{C}$. IL- 9 and IFN- $\gamma$ were tested using the kit from ebioscience. All of the ELISA assay kits were used following the supplier's instruction.

RNA isolation, reverse transcription and quantitative polymerase chain reaction ( $q P C R)$. Total RNA was extracted by E.Z.N.A. Total RNA kit I (Omega Bio-Tek, Inc., Norcross, GA, USA), and cDNA synthesis with MLV RT kit (Invitrogen) for $50 \mathrm{~min}$ at $37^{\circ} \mathrm{C}$ in the presence of oligo-dT primer. qPCR analyses were performed by Platinum ${ }^{\circledR} \mathrm{SYBR}^{\circledR}$-Green qPCR SuperMix-UDG w/ROX (Invitrogen Life Technologies, Carlsbad, CA, USA) on an Applied Biosystems 7300 Real-Time PCR System (Applied Biosystems Life Technologies, Foster City, CA, USA). Primers used were listed as follows: $\beta$-actin forward: 5'-CAGAGCAAGAGA GGCATCC-3', and reverse: 5'-CTGGGGTGTTGAAGGTCTC-3'; IL-9 forward: 5'-CCA 


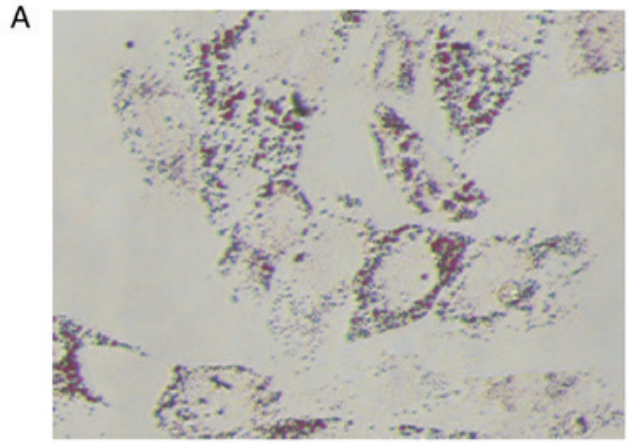

Adipogenic

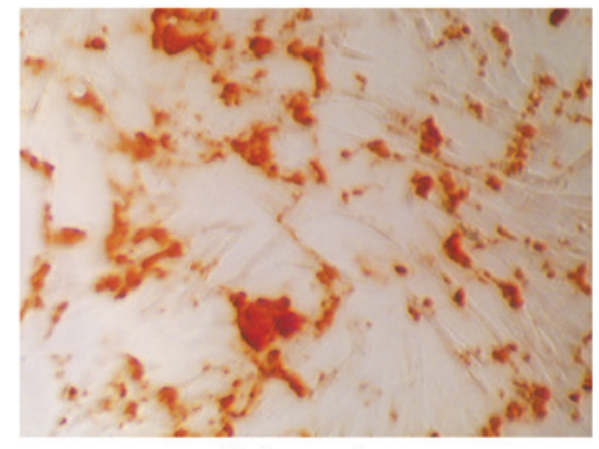

Osteogenic
B

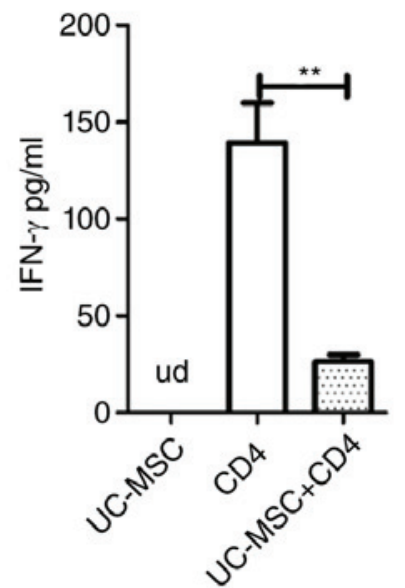

Figure 1. Characterization of UC-MSC. (A) Multilineage differentiation of UC-MSC, Alizarin red S staining for osteogenic differentiation and Oil Red $\mathrm{O}$ staining for adipogenic differentiation. (B) $4 \times 10^{3}$ UC-MSC were co-cultured with $4 \times 10^{4} \mathrm{CD}^{+} \mathrm{T}$ cells (stimulated by Dynabeads Human T-Activator $\mathrm{CD} 3 / \mathrm{CD} 28$ and $10 \mathrm{ng} / \mathrm{ml} \mathrm{IL}-2)$ for $96 \mathrm{~h}$ in a well of 96 well plates. IFN- $\gamma$ production was evaluated by ELISA. The results are presented as mean \pm standard error of the mean $\left({ }^{* *} \mathrm{P}<0.01\right.$, ud, undetectable). UC-MSC, umbilical cord derived-mesenchymal stem cells; IFN, interferon; IL, inteurleukin.

GCTTCCAAGTGCCACTGC-3', and reverse: 5'-TGCATG GTGGTATTGGTCATCTG-3'; BATF forward: 5'-ACACAG AAGGCCGACACC-3', and reverse: 5'-CTTGATCTCCTT GCGTAGAGC-3'; IRF4 forward: 5'-ACCCGCAGATGTCCA TGAG-3', and reverse: 5'-GTGGCATCATGTAGTTGTGAA CCT-3'; PU.1 forward: 5'-GAAGACCTGGTGCCCTATGA-3', and reverse: 5'-CTCTGGAGCTCCGTGAAGTT-3'; IL-10 forward: 5'-GCCTAACATGCTTCGAGATC-3', and reverse: 5'-TGATGTCTGGGTCTTGGTTC-3'.

Statistical analysis. The data were analyzed for statistic significance using the GraphPad Prism software. Data are presented as mean \pm SEM. Student's unpaired t-test was used to determine significance. $\mathrm{P}<0.05$ was considered to indicate a statistically significant difference.

\section{Results}

Characterization of UC-MSC. MSC can be isolated from umbilical cord. UC-MSC were spindle-shaped and proliferated quickly in the flask. We analyzed the surface markers of UC-MSC. UC-MSC expressed CD29, CD44, CD54, CD73, CD90, CD105, CD151 and HLA-ABC, and almost did not express CD11b,CD19,CD31,CD34,CD45,CD80,CD86,CD117 and HLA-DR. Low level of CD106 was detected on UC-MSC. The osteogenic and adipogenic potential of UC-MSC were also tested. UC-MSC were seeded and cultured in osteogenic or adipogenic medium for three weeks, and stained by alizarin red S or oil red O solution. As shown in Fig. 1A, UC-MSC can differentiate into adipocytes and osteocytes. UC-MSC could modulate the immune system, especially for Th1 immune response. To study the effect of UC-MSC on cord blood $\mathrm{CD} 4^{+} \mathrm{T}$ cells, we co-cultured UC-MSC with $\mathrm{CD} 4^{+} \mathrm{T}$ cells. As expected, we can not detect IFN- $\gamma$ in culture medium without stimulant. IL-2 $(10 \mathrm{ng} / \mathrm{ml})$ and Dynabeads Human T-Activator $\mathrm{CD} 3 / \mathrm{CD} 28$ were used to active $\mathrm{CD} 4^{+} \mathrm{T}$ cells. Fig. 1B showed that UC-MSC significantly inhibited the IFN- $\gamma$ production of active $\mathrm{CD}^{+} \mathrm{T}$ cells $(26.26 \pm 3.482 \mathrm{pg} / \mathrm{ml}$ in co-culture vs. $139.4 \pm 20.64 \mathrm{pg} / \mathrm{ml}$ in active $\mathrm{CD} 4^{+} \mathrm{T}$ alone, $\left.\mathrm{P}<0.01\right)$. These results suggested that UC-MSC isolated in our lab were effective for immune modulation, and could be used in further studies.

UC-MSC supported IL-9 production of $C D 4^{+} T$ cells. IL-9 was undetectable in culture medium of $\mathrm{CD} 4^{+} \mathrm{T}$ cells active by IL-2 and Dynabeads Human T-Activator CD3/CD28. To induce detectable IL-9 production of cord blood $\mathrm{CD} 4^{+} \mathrm{T}$ cells, additional cytokines were needed, and we added IL-4 to the culture medium. The secretion of IL-9 in UC-MSC was undetectable with or without IL-4 treatment. To explore the effect of UC-MSC on IL-9 production of cord blood CD4 ${ }^{+}$ $\mathrm{T}$ cells, UC-MSC were added to co-culture with IL-4 induced $\mathrm{CD} 4^{+} \mathrm{T}$ cells. Inactive $\mathrm{CD} 4^{+} \mathrm{T}$ cells present a smaller size than active cells (Fig. 2A and B). As shown in Fig. $2 \mathrm{C}, \mathrm{CD}^{+}{ }^{+} \mathrm{T}$ cells gathered into clusters when cultured alone. When co-cultured with UC-MSC, $\mathrm{CD}^{+}{ }^{+} \mathrm{T}$ cells grown in uniform distribution (Fig. 2D). It was likely UC-MSC changed the grow status of $\mathrm{CD}^{+} \mathrm{T}$ cells. The concentration of IL- 9 was detected by ELISA. When co-culture in the presence of IL-4, UC-MSC enhanced IL-9 production in a does dependent manner (Fig. 2E). When MSC and CD $4^{+} \mathrm{T}$ cells were co-cultured with a proportion of 1:10, the concentration of IL-9 in culture medium was largely upregulated $(235.9 \pm 31.70 \mathrm{pg} / \mathrm{ml}$ in co-culture vs . $15.86 \pm 4.26 \mathrm{pg} / \mathrm{ml}$ in active $\mathrm{CD} 4^{+} \mathrm{T}$ alone, $\left.\mathrm{P}<0.001\right)$. Although MSC from different donors showed different effects, all of them could increase soluble IL-9 in culture medium (Fig. 2F).

UC-MSC polarized $C D 4^{+} T$ to IL-9 producing cells. Increased soluble IL-9 in culture medium of $\mathrm{CD}^{+} \mathrm{T}$ cells were detected when co-cultured with UC-MSC, suggested that UC-MSC might enhance polarization of $\mathrm{CD}^{+} \mathrm{T}$ cells to produce IL-9. Intracellular staining showed that proportion of IL-9 producing cells was increased (Fig. 3A). More $\mathrm{CD} 4^{+} \mathrm{T}$ cells were polarized to IL-9 producing cells when co-cultured with UC-MSC. $\mathrm{CD}^{+} \mathrm{T}$ cells were isolated and expression of $\mathrm{Th} 9$ related genes in the $\mathrm{CD}^{+}{ }^{+} \mathrm{T}$ cells were examined by real-time PCR after 4 days culture. The relative mRNA of IL-9 in CD4 ${ }^{+}$ 

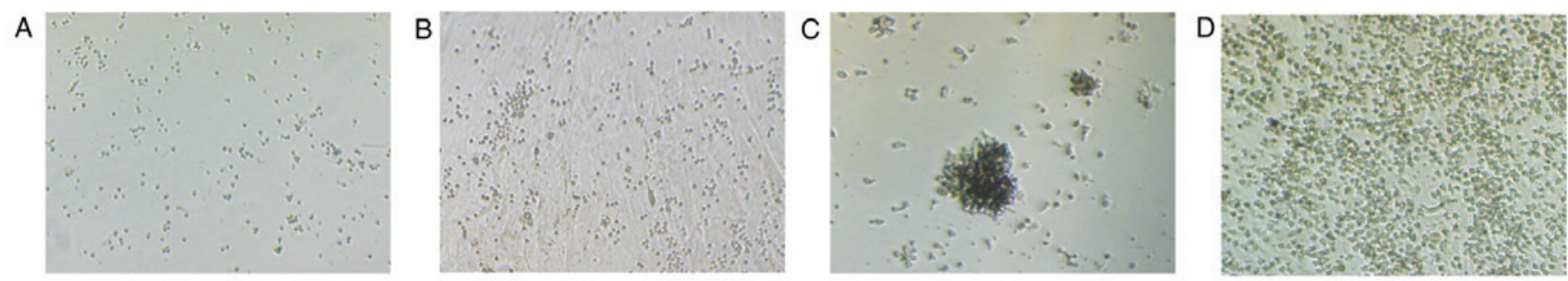

E

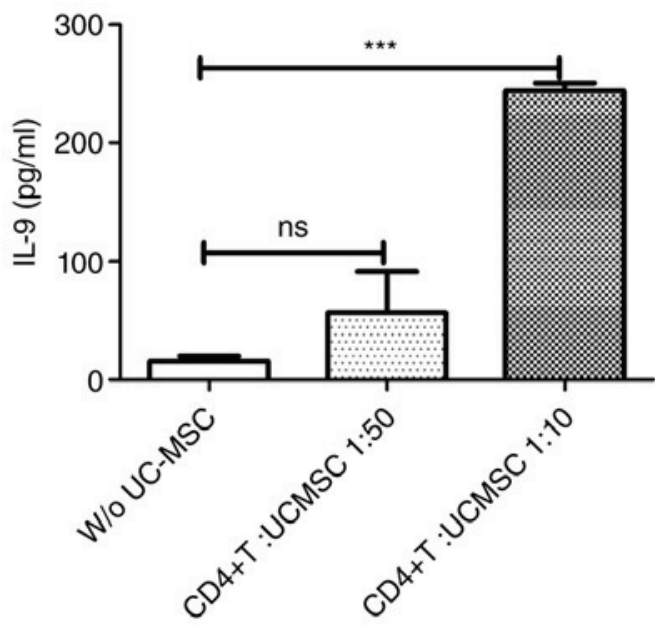

$\mathrm{F}$

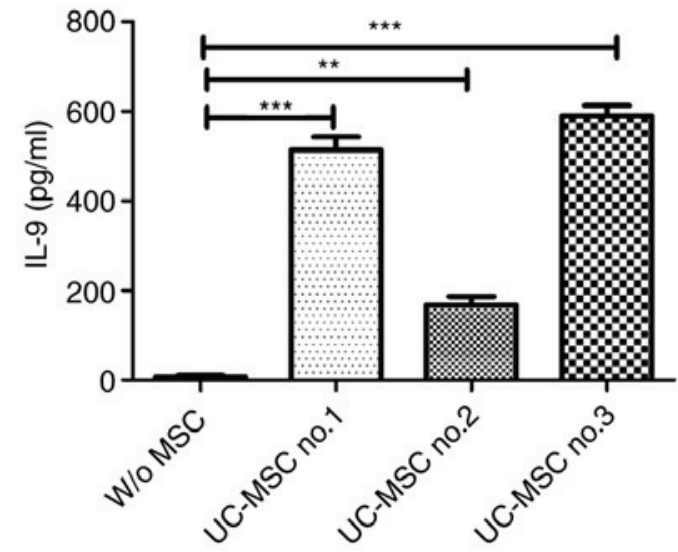

Figure 2. UC-MSC supported IL-9 production CD4 $4^{+} \mathrm{T}$ cells. $4 \times 10^{4} \mathrm{CD}^{+} \mathrm{T}$ cells (stimulated by Dynabeads Human T-Activator CD3/CD28, $10 \mathrm{ng} / \mathrm{ml} \mathrm{IL}-2$ and $20 \mathrm{ng} / \mathrm{ml} \mathrm{IL}-4)$ were co-cultured with $4 \times 10^{3} \mathrm{UC}-\mathrm{MSC}\left(\mathrm{CD} 4^{+} \mathrm{T}: \mathrm{UC}-\mathrm{MSC}, 1: 10\right)$ were for $96 \mathrm{~h}$ in a well of 96 well plates. The growths of CD4 $4^{+} \mathrm{T}$ cells were observed. Images were taken by OLYMPUS DP72. Magnification, x40. (A) Without UC-MSC in the absent of stimuli. (B) With UC-MSC in the absent of stimuli. (C) Without UC-MSC in the present of stimuli. (D) With UC-MSC in the present of stimuli. (E) $4 \times 10^{3}$ (CD4 ${ }^{+}$T:UC-MSC, 1:10 ) or 8x10 $\left(\mathrm{CD} 4^{+} \mathrm{T}\right.$ :UC-MSC, 1:50 ) UC-MSC were used to co-culture with $\mathrm{CD}^{+} \mathrm{T}$ cells. Concentrations of IL-9 in culture medium were detected by ELISA. The results are presented as mean \pm standard error of the mean (ns, not significant; ${ }^{* * * *} \mathrm{P}<0.01$ ). $(\mathrm{F}) 4 \times 10^{3} \mathrm{UC}-\mathrm{MSC}$ of three different individual origins (UC-MSC no. 1 , UC-MSC no. 2 and UC-MSC no. 3 ) were used. Concentrations of IL-9 in culture medium were detected by ELISA. The results are presented as mean \pm SEM $\left({ }^{* *} \mathrm{P}<0.01 ;{ }^{* * *} \mathrm{P}<0.001\right)$. W/o, without; UC-MSC, umbilical cord derived-mesenchymal stem cells; IL, inteurleukin.

T cells were raised (Fig. 3B). Moreover, expression of BATF, IRF4 and PU.1 were upregulated. To our surprise, IL-10 was not upregulated by UC-MSC, suggesting a different regulation pattern with IL-9 (Fig. 3B).

Cell-cell contact mediated the promotion effect of UC-MSC on IL-9 production of $\mathrm{CD}^{+} \mathrm{T}$ cells. Role of cell-cell contact in MSC mediate immune modulation was not clear yet. In order to test whether cell-cell contact play a role in MSC mediate promotion of IL-9 production, transwell was used. For transwell analyze, UC-MSC were seeded into the upper chamber, and $\mathrm{CD}^{+} \mathrm{T}$ cells were seeded into the low chamber. Cells in the transwell group were more likely to gather together than the co-culture group (Fig. 4A and B), suggesting different growth state. Unlike in direct co-culture, UC-MSC failed to support IL-9 production of $\mathrm{CD}^{+} \mathrm{T}$ cells in transwell system (Fig. 4C, $\mathrm{P}>0.05)$. These results suggest thaT cell-cell contact between $\mathrm{CD}^{+}{ }^{+} \mathrm{T}$ cells and UC-MSC is critical for its supportive effect on IL-9 producing $\mathrm{CD}^{+} \mathrm{T}$ cells.

Supportive effect of UC-MSC on IL-9 production of $C B C D 4^{+}$ $T$ cells is CD106 dependent. As cell-cell contact is critical for UC-MSC mediated enhancement of IL-9 production for $\mathrm{CD} 4^{+} \mathrm{T}$ cells, we supposed that the molecules expressed on the surface of MSC might play a role in this process. CD106 can be up regulated in many conditions, so we tested their expression.
CD106 could be upregulate by IL-4, and its expression was further up regulated on UC-MSC in this co-culture (Fig. 5A). The change of CD106 indicated their participation in the regulation of Th9. To test their roles, CD106 blocking antibody were added into the co-culture system. After blocking CD106, the effect of UC-MSC was significant impaired (Fig. 5B, $225.5 \pm 19.37 \mathrm{pg} / \mathrm{ml}$ in isotype control group; $143.6 \pm 8.72 \mathrm{pg} / \mathrm{ml}$ in anti CD106 group, $\mathrm{P}<0.05)$. Blocking CD106 mediate adherence did not reverse the promotion effect of UC-MSC entirely, so other molecules may also play a role.

\section{Discussion}

In the present study, we discovered that short term of UC-MSC treatment could increase IL-9 production of CD4 ${ }^{+}$ $\mathrm{T}$ cells, and up regulate $\mathrm{Th} 9$ related transcription factors BATF, IRF4 and PU.1. This effect was mediate mainly by cell- cell contact, and adhesion molecules CD106 participated in this process.

MSC can modulate T cells, B cells, NK cells, DC and macrophages $(21,22)$. The effects of MSC on many subsets of $\mathrm{CD}^{+} \mathrm{T}$ cells were published. MSC inhibited Th1, promoted Treg, but the effect on Th17 were confusion $(6,7,23)$. Our study suggested that Th9 were promoted by MSC. Th9 has been suggested to participate in many biological progresses. In many autoimmune diseases, expression of IL-9 was abnormal. 
A

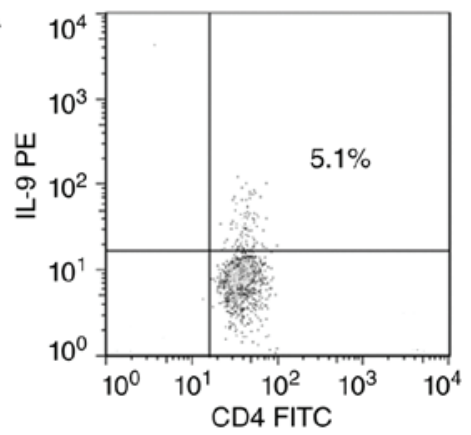

W/O UC-MSC

B
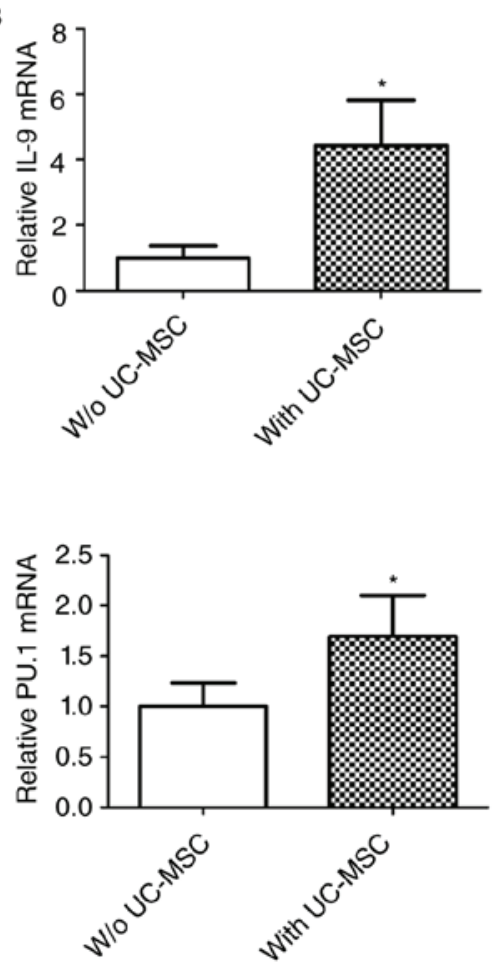

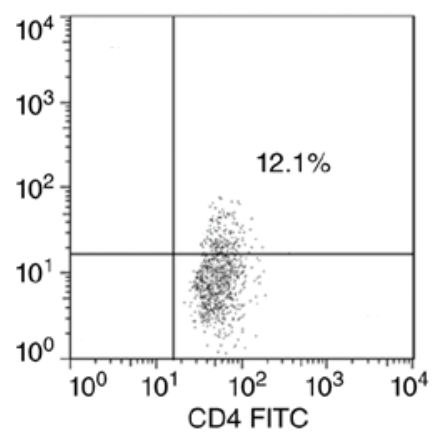

With UC-MSC
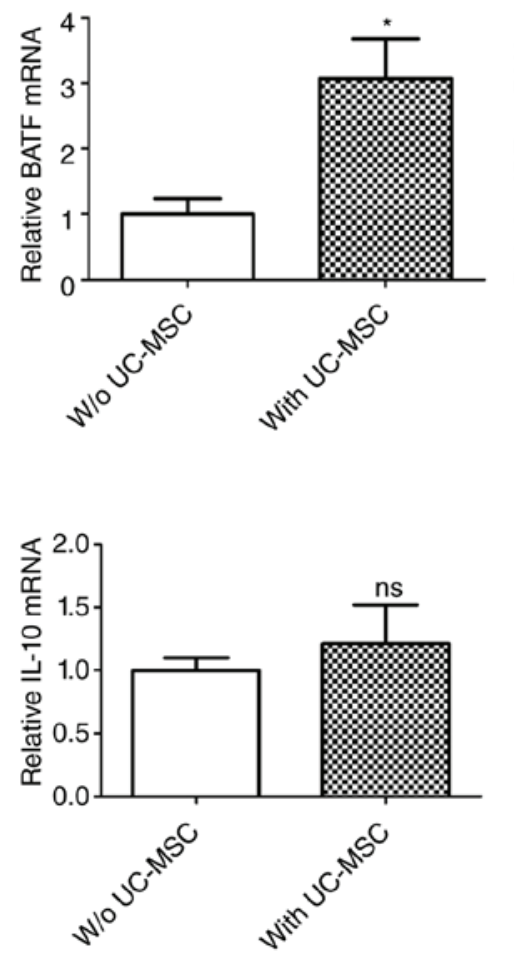
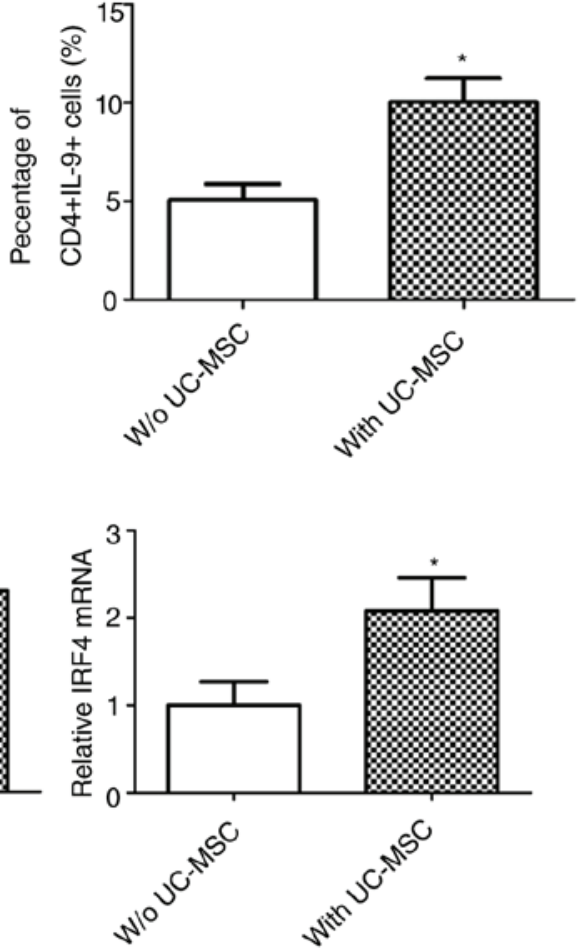

Figure 3. UC-MSC polarized CD4 ${ }^{+} \mathrm{T}$ to IL-9 producing cells. $4 \times 10^{4} \mathrm{CD}^{+} \mathrm{T}$ cells (stimulated by Dynabeads Human T-Activator CD3/CD28, $10 \mathrm{ng} / \mathrm{ml} \mathrm{IL}-2$ and $20 \mathrm{ng} / \mathrm{ml} \mathrm{IL}-4)$ were co-cultured with $4 \times 10^{3} \mathrm{UC}-\mathrm{MSC}$ in a well of 96 well plates.(A) CD4 ${ }^{+} \mathrm{T}$ cells were stimulated for $5 \mathrm{~h}$ with PMA (50 ng/ml; Sigma) and ionomycin $1 \mu \mathrm{g} / \mathrm{ml}$; Calbiochem; EMD Millipore) in the presence of Golgiplug (BD Biosciences) after $91 \mathrm{~h}$ of culture. Intracellular cytokine expression was analyzed by flow cytometry. Graph of typical result were show on the left. Results of three separate experiments were show on the right. The results are presented as mean \pm standard error of the mean ( $(\mathrm{P}<0.05)(\mathrm{B}) \mathrm{CD} 4^{+} \mathrm{T}$ cells were isolate $96 \mathrm{~h}$ later, and the relative expression of IL-9, BATF, IRF4, PU.1 and IL-10 in CD4 $4^{+} \mathrm{T}$ cells were measured by qPCR (ns, not significant; " $\mathrm{P}<0.05$ ). W/o, without; UC-MSC, umbilical cord derived-mesenchymal stem cells; IL, inteurleukin; qPCR, quantitative polymerase chain reaction.

IL-9 have been shown to up regulate in asthma (24), atopic dermatitis (25), systemic lupus erythematosus (26) and atherosclerosis (27). A study showed that IL-9 is required for TSLP-induced allergic inflammation (28). These researches highlight the role of IL-9 in immune responses. This supportive effect should be taken into consideration when MSC were used for treatment of autoimmune diseases. Moreover, Th9 were recruitment to malignant pleural effusion (29) and IL-9 inhibited tumor growth (30). MSC might regulate tumor cells directly and indirectly and the role of Th9 in tumor immunity, suggested a complex role that MSC play, and prompted a new way of how MSC affects the tumor.

MSC regulates the immune cell by cell-cell contact and soluble factors. Soluble factors were supposed to be important for immune modulation of MSC. MSC modulate the immune response partly via soluble factors such as PGE2 (8), IDO1 (9), TGF- $\beta 1$ (31), hepatocyte growth factor (HGF) (32), IL-6 (33), HLA-G (34), nitric oxide (NO) (35), or Galectin-1 (36). The cell surface molecules that participate in immune modulation of MSC were also reported. Jagged-2 (37), FAS ligand (38), CD54 (11) and CD106 (11) were included in the immune modulation of MSC. MSC inhibits Th1 response mainly by soluble factors like PGE2 and IDO1 $(8,10)$, and cell-cell contact only plays a supplementary role (11). For regulation of Treg and Th17, cell-cell contact and soluble factors were both important $(7,39)$. In our study, we discovered that CD106 was critical for the Th9 supportive effect of MSC. Our results suggested that MSC could regulate different $\mathrm{CD} 4^{+} \mathrm{T}$ cell subset in different ways. 
A

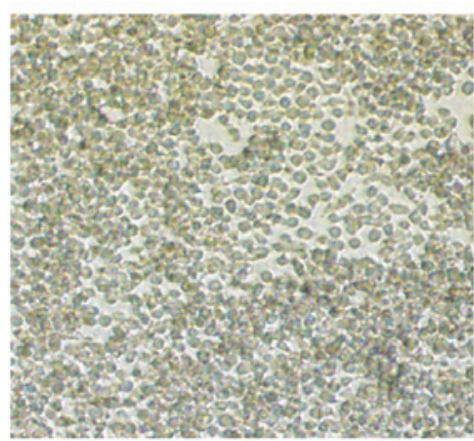

B

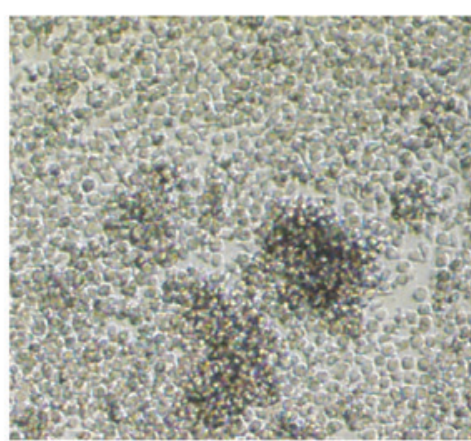

C

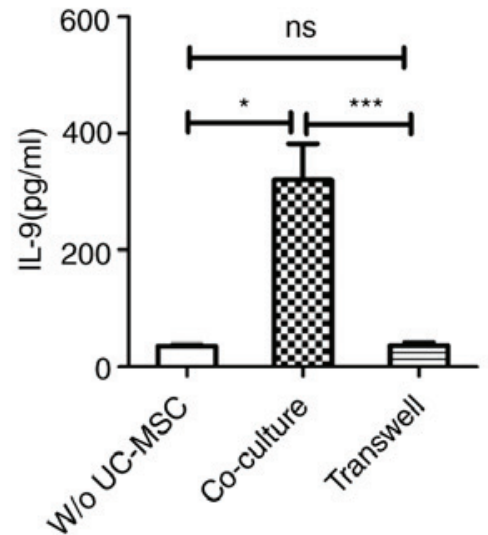

Figure 4. Cell-cell contact mediated the promotion effect of UC-MSC on IL-9 production of CD4 $4^{+} \mathrm{T}$ cells. $2 \times 10^{4} \mathrm{UC}-\mathrm{MSC}$ were plated on the upper chamber of a well of 24-well transwell plate. $2 \times 10^{5} \mathrm{CD} 4{ }^{+} \mathrm{T}$ cells (stimulated by Dynabeads Human T-Activator CD3/CD28, $10 \mathrm{ng} / \mathrm{ml} \mathrm{IL-2} \mathrm{and} 20 \mathrm{ng} / \mathrm{ml} \mathrm{IL-4)} \mathrm{were} \mathrm{added}$ on the lower chamber. Same cells were used in co-culture. The cells were cultured for $96 \mathrm{~h}$. The growths of CD4+ T cells were observed. Magnification, $\mathrm{x} 40$. (A) Co-culture. (B) Transwell. (C) Concentrations of IL-9 in culture medium were detected by ELISA. The results are presented as mean \pm standard error of the mean $\left({ }^{*} \mathrm{P}<0.05 ;{ }^{* * *} \mathrm{P}<0.001 ;\right.$ ns, not significant). W/o, without; UC-MSC, umbilical cord derived-mesenchymal stem cells; IL, inteurleukin.
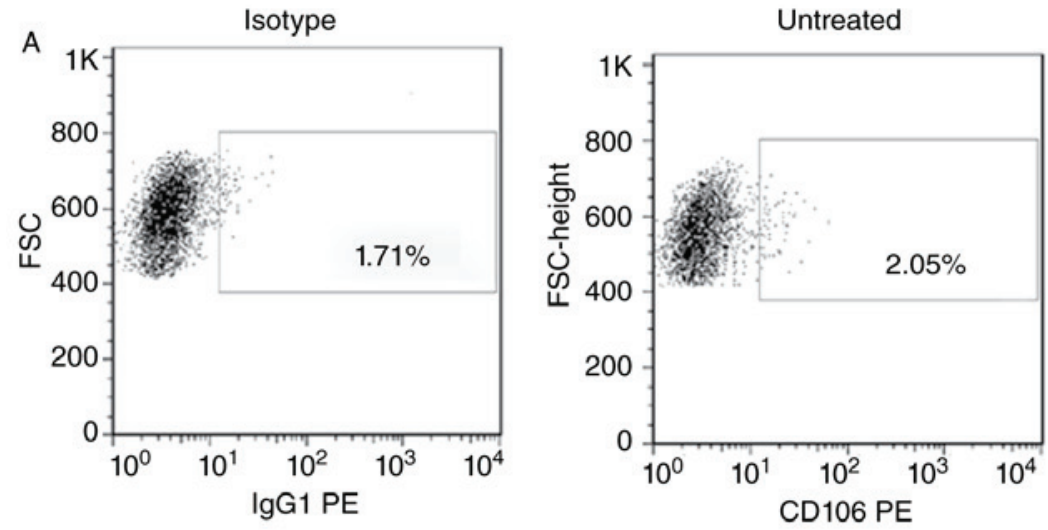

B
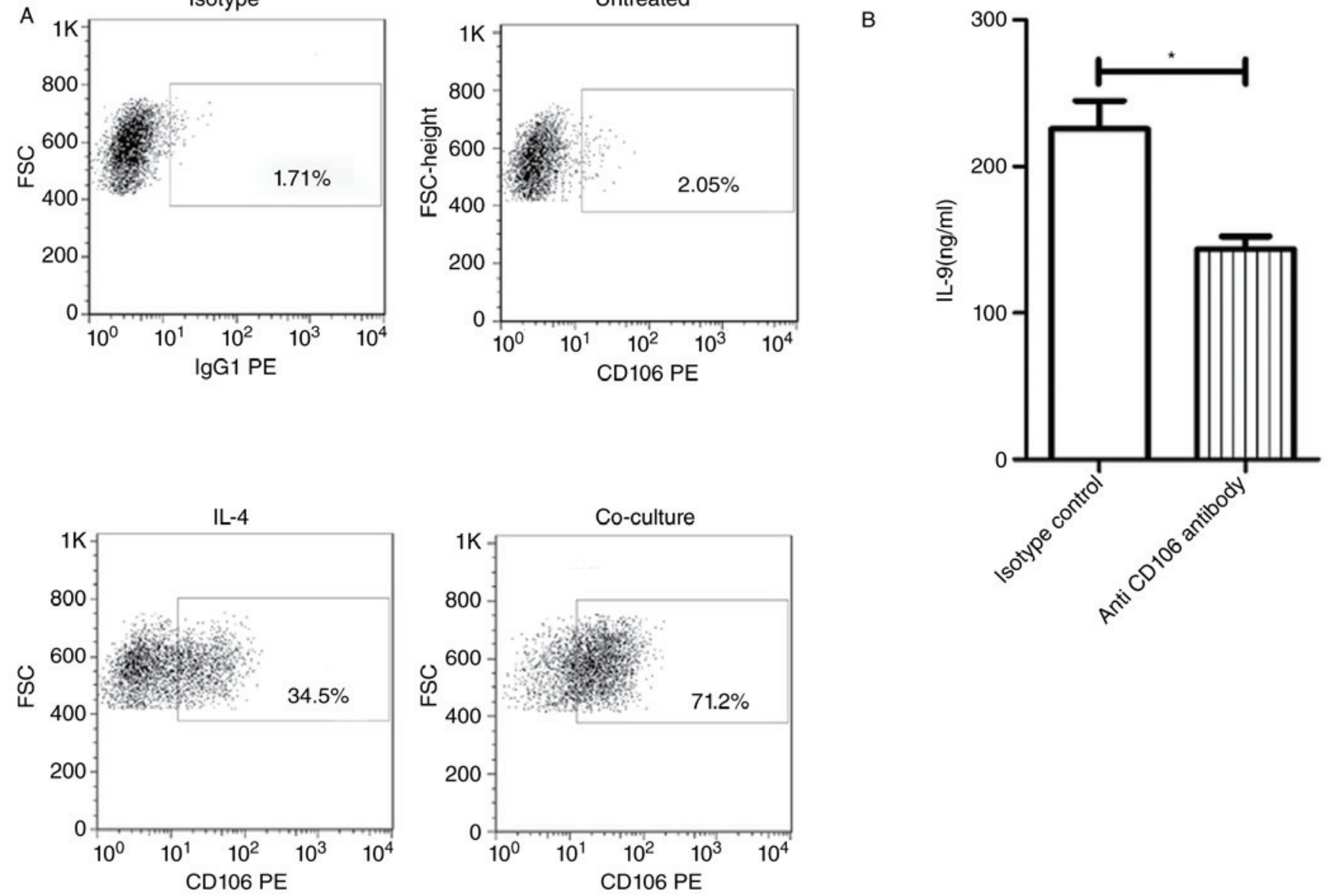

Figure 5. CD106 participated in UC-MSC mediated supportive effect on IL-9 production of CD4 $4^{+} \mathrm{T}$ cells. (A) $2 \times 10^{5} \mathrm{CD} 4^{+} \mathrm{T}$ cells (stimulated by Dynabeads Human T-Activator CD3/CD28, $10 \mathrm{ng} / \mathrm{ml} \mathrm{IL-2} \mathrm{and} 20 \mathrm{ng} / \mathrm{ml} \mathrm{IL-4)} \mathrm{were} \mathrm{co-cultured} \mathrm{with} \mathrm{2 \times 10} 4$ UC-MSC in a well of 24 well plates for $96 \mathrm{~h}$. UC-MSC was isolate, and tested for CD106 by flow cytometry. Untreated UC-MSC or IL-4 (20 ng/ml) treated UC-MSC were served as controls. (B) $4 \times 10^{4}$ CD4 $4^{+}$T cells

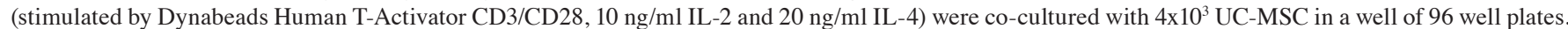
$5 \mu \mathrm{g} / \mathrm{ml}$ of isotype control or CD106 neutralizing antibody were added to the culture, and the cells were cultured for $96 \mathrm{~h}$. Concentrations of IL-9 in culture medium were detected by ELISA. The results are presented as mean \pm standard error of the mean (" $\mathrm{P}<0.05)$. UC-MSC, umbilical cord derived-mesenchymal stem cells; IL, inteurleukin

In our study, we added IL-4 to the culture medium and the role of IL-4 may not just in inducing IL-9. Pro-inflammatory cytokine IFN- $\gamma$, TNF- $\alpha$ and IL-1 $\beta$, have been shown to be important in the immunomodulatory properties of MSC (22). IFN- $\gamma$ 
could induce IDOI in MSC, which inhibited T cell proliferation (9). Our group discovered that IL-1 $\beta$ enhanced the secretion of PGE2 from UC-MSC, and resulted in a stronger inhibition for proliferation and IFN- $\gamma$ production of T cells (40). In mouse, IFN- $\gamma$, TNF- $\alpha$ and IL- $1 \beta$ combination provoke the expression of high levels of inducible NO synthase (iNOS), chemokines and adhesion molecules for MSC, and induce immunosuppression by MSC (35). IL-4 could enhance expression of CD106 in UC-MSC, and it is reported that IL-4 could also increase CD106 expression of BM stromal cells (41) and endothelium cells (42), so we suggest that IL-4 might play multiple roles in inducing Th9.

Our previous study have proved that CD106 identifies a subpopulation of chorionic villi-MSC with strong immunomodulatory properties for peripheral blood mononuclear cells and Th1 cells (43). Besides highly expression of CD106, there was also a upregulation of $C O X-2, I L-1 A, I L 1 B$ and $I L-6$ (43). In the present study, CD106 was important in regulation of Th9 and the effects of CD106 ${ }^{+} \mathrm{MSC}$ on Th9 are not known yet.

In conclusion, we discovered the IL-9 production of $\mathrm{CD}^{+}$ $\mathrm{T}$ cells can be enhanced by UC-MSC, mostly via cell-cell contact, and CD106 participated in the supportive effect. Further studies are needed to for understanding the effect of CD106 ${ }^{+} \mathrm{MSC}$ on Th9, and the usage of MSC on Th9 related disease.

\section{Acknowledgements}

We thank Professor Rui He, Hui Zhao and Mr. Shaoguang Yang for providing valuable suggestions. This study was supported by National Basic Research Program of China (nos. 2011CB964800 and 2011CB964802), National Science and Technology Support Program (no. 2013BAI01B09), National Natural Science Foundation of China (nos. 81330015 and 31470951), Natural Foundation of Zhejiang (nos. LQ12H16001 and LQ16C120001).

\section{References}

1. Jiang Y, Jahagirdar BN, Reinhardt RL, Schwartz RE, Keene CD, Ortiz-Gonzalez XR, Reyes M, Lenvik T, Lund T, Blackstad M, et al: Pluripotency of mesenchymal stem cells derived from adult marrow. Nature 418: 41-49, 2002.

2. Pittenger MF, Mackay AM, Beck SC, Jaiswal RK, Douglas R, Mosca JD, Moorman MA, Simonetti DW, Craig S and Marshak DR: Multilineage potential of adult human mesenchymal stem cells. Science 284: 143-147, 1999.

3. Zuk PA, Zhu M, Ashjian P, De Ugarte DA, Huang JI, Mizuno H, Alfonso ZC, Fraser JK, Benhaim P and Hedrick MH: Human adipose tissue is a source of multipotent stem cells. Mol Biol Cell 13: 4279-4295, 2002.

4. Lu LL, Liu YJ, Yang SG, Zhao QJ, Wang X, Gong W, Han ZB, $\mathrm{Xu} \mathrm{ZS}, \mathrm{Lu}$ YX, Liu D, et al: Isolation and characterization of human umbilical cord mesenchymal stem cells with hematopoiesis-supportive function and other potentials. Haematologica 91: 1017-1026, 2006.

5. In't Anker PS, Scherjon SA, Kleijburg-van der Keur C, de Groot-Swings GM, Claas FH, Fibbe WE and Kanhai HH: Isolation of mesenchymal stem cells of fetal or maternal origin from human placenta. Stem Cells 22: 1338-1345, 2004.

6. Aggarwal S and Pittenger MF: Human mesenchymal stem cells modulate allogeneic immune cell responses. Blood 105: $1815-1822,2005$

7. Ghannam S, Pène J, Torcy-Moquet G, Jorgensen C and Yssel H: Mesenchymal stem cells inhibit human Th17 cell differentiation and function and induce a $\mathrm{T}$ regulatory cell phenotype. J Immunol 185: 302-312, 2010.
8. Chen K, Wang D, Du WT, Han ZB, Ren H, Chi Y, Yang SG, Zhu D, Bayard F and Han ZC: Human umbilical cord mesenchymal stem cells hUC-MSCs exert immunosuppressive activities through a PGE2-dependent mechanism. Clin Immunol 135: 448-458, 2010.

9. Meisel R, Zibert A, Laryea M, Göbel U, Däubener W and Dilloo D: Human bone marrow stromal cells inhibit allogeneic T-cell responses by indoleamine 2,3-dioxygenase-mediated tryptophan degradation. Blood 103: 4619-4621, 2004.

10. Krampera M, Cosmi L, Angeli R, Pasini A, Liotta F, Andreini A, Santarlasci V, Mazzinghi B, Pizzolo G, Vinante F, et al: Role for interferon-gamma in the immunomodulatory activity of human bone marrow mesenchymal stem cells. Stem Cells 24: 386-398, 2006.

11. Ren G, Zhao X, Zhang L, Zhang J, L'Huillier A, Ling W, Roberts AI, Le AD, Shi S, Shao C and Shi Y: Inflammatory cytokine-induced intercellular adhesion molecule-1 and vascular cell adhesion molecule- 1 in mesenchymal stem cells are critical for immunosuppression. J Immunol 184: 2321-2328, 2010.

12. Sun J, Han ZB, Liao W, Yang SG, Yang Z, Yu J, Meng L, Wu R and Han ZC: Intrapulmonary delivery of human umbilical cord mesenchymal stem cells attenuates acute lung injury by expanding $\mathrm{CD} 4^{+} \mathrm{CD} 25^{+}$Forkhead Boxp3 (FOXP3) ${ }^{+}$regulatory $\mathrm{T}$ cells and balancing anti- and pro-inflammatory factors. Cell Physiol Biochem 27: 587-596, 2011.

13. Liang L, Dong C, Chen X, Fang Z, Xu J, Liu M, Zhang X, Gu DS, Wang D, Du W, et al: Human umbilical cord mesenchymal stem cells ameliorate mice trinitrobenzene sulfonic acid (TNBS)-induced colitis. Cell Transplant 20: 1395-1408, 2011.

14. Sun L, Wang D, Liang J, Zhang H, Feng X, Wang H, Hua B, Liu B, Ye S, Hu X, et al: Umbilical cord mesenchymal stem cell transplantation in severe and refractory systemic lupus erythematosus. Arthritis Rheum 62: 2467-2475, 2010.

15. Goswami R and Kaplan MH: A brief history of IL-9. J Immunol 186: 3283-3288, 2011.

16. Veldhoen M, Uyttenhove C, van Snick J, Helmby $\mathrm{H}$, Westendorf A, Buer J, Martin B, Wilhelm C and Stockinger B: Transforming growth factor-beta 'reprograms' the differentiation of T helper 2 cells and promotes an interleukin 9-producing subset. Nat Immunol 9: 1341-1346, 2008.

17. Dardalhon V, Awasthi A, Kwon H, Galileos G, Gao W, Sobel RA, Mitsdoerffer M, Strom TB, Elyaman W, Ho IC, et al: IL-4 inhibits TGF-beta-induced Foxp $3^{+} \mathrm{T}$ cells and, together with TGF-beta, generates IL-9+ IL-10+ Foxp3(-) effector T cells. Nat Immunol 9: 1347-1355, 2008.

18. Elyaman W, Bradshaw EM, Uyttenhove C, Dardalhon V, Awasthi A, Imitola J, Bettelli E, Oukka M, van Snick J, Renauld JC, et al: IL-9 induces differentiation of TH17 cells and enhances function of FoxP $3^{+}$natural regulatory T cells. Proc Natl Acad Sci USA 106: 12885-12890, 2009.

19. Wong MT, Ye JJ, Alonso MN, Landrigan A, Cheung RK, Engleman E and Utz PJ: Regulation of human Th9 differentiation by type I interferons and IL-21. Immunol Cell Biol 88: 624-631, 2010.

20. Anuradha R, George PJ, Hanna LE, Chandrasekaran V, Kumaran P, Nutman TB and Babu S: IL-4-, TGF- $\beta-$, and IL-1-dependent expansion of parasite antigen-specific Th9 cells is associated with clinical pathology in human lymphatic filariasis. J Immunol 191: 2466-2473, 2013.

21. Nauta AJ and Fibbe WE: Immunomodulatory properties of mesenchymal stromal cells. Blood 110: 3499-3506, 2007.

22. Shi Y, Hu G, Su J, Li W, Chen Q, Shou P, Xu C, Chen X, Huang Y, Zhu Z, et al: Mesenchymal stem cells: A new strategy for immunosuppression and tissue repair. Cell Res 20: 510-518, 2010.

23. Guo Z, Zheng C, Chen Z, Gu D, Du W, Ge J, Han Z and Yang R: Fetal BM-derived mesenchymal stem cells promote the expansion of human Th17 cells, but inhibit the production of Th1 cells. Eur J Immunol 39: 2840-2849, 2009.

24. Shimbara A, Christodoulopoulos P, Soussi-Gounni A, Olivenstein R, Nakamura Y, Levitt RC, Nicolaides NC, Holroyd KJ, Tsicopoulos A, Lafitte JJ, et al: IL-9 and its receptor in allergic and nonallergic lung disease: Increased expression in asthma. J Allergy Clin Immunol 105: 108-115, 2000.

25. Ciprandi G, De Amici M, Giunta V, Marseglia A and Marseglia G: Serum interleukin-9 levels are associated with clinical severity in children with atopic dermatitis. Pediatr Dermatol 30: 222-225, 2013.

26. Ouyang H, Shi Y, Liu Z, Feng S, Li L, Su N, Lu Y and Kong S: Increased interleukin 9 and CD4 $4^{+} \mathrm{IL}-9^{+} \mathrm{T}$ cells in patients with systemic lupus erythematosus. Mol Med Rep 7: 1031-1037, 2013. 
27. Gregersen I,Skjelland M,Holm S,Holven KB,Krogh-Sørensen K, Russell D, Askevold ET, Dahl CP, Ørn S, Gullestad L, et al: Increased systemic and local interleukin 9 levels in patients with carotid and coronary atherosclerosis. PLoS One 8: e72769, 2013.

28. Yao W, Zhang Y, Jabeen R, Nguyen ET, Wilkes DS, Tepper RS, Kaplan MH and Zhou B: Interleukin-9 is required for allergic airway inflammation mediated by the cytokine TSLP. Immunity 38: 360-372, 2013

29. Bu XN, Zhou Q, Zhang JC, Ye ZJ, Tong ZH and Shi HZ: Recruitment and phenotypic characteristics of interleukin 9-producing $\mathrm{CD} 4^{+} \mathrm{T}$ cells in malignant pleural effusion. Lung 191: 385-389, 2013.

30. Purwar R, Schlapbach C, Xiao S, Kang HS, Elyaman W, Jiang X, Jetten AM, Khoury SJ, Fuhlbrigge RC, Kuchroo VK, et al: Robust tumor immunity to melanoma mediated by interleukin-9-producing T cells. Nat Med 18: 1248-1253, 2012.

31. Nemeth K, Keane-Myers A, Brown JM, Metcalfe DD, Gorham JD, Bundoc VG, Hodges MG, Jelinek I, Madala S, Karpati S and Mezey E: Bone marrow stromal cells use TGF-beta to suppress allergic responses in a mouse model of ragweed-induced asthma. Proc Natl Acad Sci USA 107: 5652-5657, 2010.

32. Di Nicola M, Carlo-Stella C, Magni M, Milanesi M, Longoni PD, Matteucci P, Grisanti S and Gianni AM: Human bone marrow stromal cells suppress T-lymphocyte proliferation induced by cellular or nonspecific mitogenic stimuli. Blood 99: 3838-3843 2002.

33. Nauta AJ, Kruisselbrink AB, Lurvink E, Willemze R and Fibbe WE: Mesenchymal stem cells inhibit generation and function of both $\mathrm{CD} 34^{+}$-derived and monocyte-derived dendritic cells. J Immunol 177: 2080-2087, 2006.

34. Selmani Z, Naji A, Gaiffe E, Obert L, Tiberghien P, Rouas-Freiss N, Carosella ED and Deschaseaux F: HLA-G is a crucial immunosuppressive molecule secreted by adult human mesenchymal stem cells. Transplantation 87 (9 Suppl): S62-S66, 2009.

35. Ren G, Zhang L, Zhao X, Xu G, Zhang Y, Roberts AI, Zhao RC and Shi Y: Mesenchymal stem cell-mediated immunosuppression occurs via concerted action of chemokines and nitric oxide. Cell Stem Cell 2: 141-150, 2008.
36. Gieseke F, Böhringer J, Bussolari R, Dominici M, Handgretinger R and Müller I: Human multipotent mesenchymal stromal cells use galectin-1 to inhibit immune effector cells. Blood 116: 3770-3779, 2010.

37. Zhang B, Liu R, Shi D, Liu X, Chen Y, Dou X, Zhu X, Lu C, Liang W, Liao L, et al: Mesenchymal stem cells induce mature dendritic cells into a novel Jagged-2-dependent regulatory dendritic cell population. Blood 113: 46-57, 2009.

38. Akiyama K, Chen C, Wang D, Xu X, Qu C, Yamaza T, Cai T, Chen W, Sun L and Shi S: Mesenchymal-stem-cell-induced immunoregulation involves FAS-ligand-/FAS-mediated $\mathrm{T}$ cell apoptosis. Cell Stem Cell 10: 544-555, 2012.

39. English K, Ryan JM, Tobin L, Murphy MJ, Barry FP and Mahon BP: Cell contact, prostaglandin E(2) and transforming growth factor beta 1 play non-redundant roles in human mesenchymal stem cell induction of $\mathrm{CD} 4{ }^{+} \mathrm{CD} 25$ (High) forkhead box $\mathrm{P}^{+}$regulatory T cells. Clin Exp Immunol 156: 149-160, 2009.

40. Wang D, Chen K, Du WT, Han ZB, Ren H, Chi Y, Yang SG, Bayard F, Zhu D and Han ZC: $\mathrm{CD} 14^{+}$monocytes promote the immunosuppressive effect of human umbilical cord matrix stem cells. Exp Cell Res 316: 2414-2423, 2010.

41. Simmons PJ, Masinovsky B, Longenecker BM, Berenson R, Torok-Storb B and Gallatin WM: Vascular cell adhesion molecule- 1 expressed by bone marrow stromal cells mediates the binding of hematopoietic progenitor cells. Blood 80: 388-395, 1992.

42. Schleimer RP, Sterbinsky SA, Kaiser J, Bickel CA, Klunk DA, Tomioka K, Newman W, Luscinskas FW, Gimbrone MA Jr, McIntyre BW, et al: IL-4 induces adherence of human eosinophils and basophils but not neutrophils to endothelium. Association with expression of VCAM-1. J Immunol 148: 1086-1092, 1992.

43. Yang ZX, Han ZB, Ji YR, Wang YW, Liang L, Chi Y, Yang SG, Li LN, Luo WF, Li JP, et al: CD106 identifies a subpopulation of mesenchymal stem cells with unique immunomodulatory properties. PLoS One 8: e59354, 2013. 